\title{
Consumer Reaction and the Effectiveness of Celebrity Endorsed Advertising: A Survey-Based Econometric Analysis
}

\author{
Yanqing Jiang \& Lin Fang \\ School of Economics and Finance, Shanghai International Studies University, Shanghai, P. R. China \\ Correspondence: Yanqing Jiang, School of Economics and Finance, Shanghai International Studies University, No. \\ 1550 Wenxiang Rd., Shanghai 201620, P. R. China
}

\author{
Received: May 1, 2014 Accepted: May 15, 2014 Available online: May 28, 2014 \\ doi:10.11114/smc.v2i1.400 \\ URL: http://dx.doi.org/10.11114/10.11114/smc.v2i1.400
}

\begin{abstract}
In this study, we apply an econometric methodology to empirically examine the potential roles of a host of key factors on the part of the consumer in affecting the level of effectiveness (persuasiveness) of celebrity endorsement in advertising. Based on first-hand data obtained from surveys and using an econometric approach, we design and implement our empirical analysis. The analysis leads to estimation results showing that gender of the consumer matters critically in determining the level of effectiveness that persuasion of celebrity endorsed advertising could possibly reach. Through our regression exercise, we also find that the effectiveness of celebrity endorsed advertising crucially depends on the level of consumer income. In addition, our regression results also suggest that the socio-cultural background of the consumer plays a critical role in affecting the persuasiveness level of celebrity endorsed advertising.
\end{abstract}

Keywords: consumer reaction, advertising, celebrity endorsement, econometric analysis

\section{Introduction}

Celebrity endorsement in advertising can be understood as a channel of communication where celebrities act as spokesperson of a commercial product and by extending their popularity and personality they certifies the product's claim and position (Friedman and Friedman, 1979). This study is a survey-based econometric analysis aiming to explore the potential roles of a host of key factors on the part of the consumer in affecting the level of persuasiveness provided by celebrity endorsement in advertising. Specifically, we focus on the effects of various consumer characteristics on the expected persuasiveness level of celebrity endorsed advertising. Our research is motivated by the fact that the level of effectiveness of celebrity endorsed advertising depends crucially on the reaction of the potential consumers, which is in turn determined on the various consumer characteristics. Therefore, learning more about consumer reaction and consumer characteristics underlying the reaction can substantially benefit the advertiser in making cost-effective decisions in advertising.

The entire paper is structured as follows. In Section 2, we discuss relevant literature and provide theoretical reasoning regarding the central issue of this study in order to motivate our quantitative and econometric analysis in subsequent sections. In Section 3, we discuss our survey-based approach by describing the sample as well as related data and variables. This section also provides descriptive statistics of our sample in preparation of the regression analysis to be implemented in the next section. Section 4 contains our econometric analysis, which is carried out in the form of running relevant regressions based on our estimation models. Our major regression results are presented and discussed. Finally, Section 5 concludes this study.

\section{Literature Review and Theoretical Reasoning}

Various researchers have given their definitions of celebrity and celebrity endorsement. Friedman and Friedman (1979), for example, treat the term celebrity as an individual who is known to the public (actors, sports figures, entertainers, etc.) for his or her achievements in areas other than that of the product class endorsed, and consider celebrity endorsement a channel of communication where celebrities act as spokesperson of the brand and by extending their popularity and personality they certifies the brand's claim and position. McCracken (1989) thinks celebrities are individuals who enjoy public recognition and take advantage of this recognition on behalf of a consumer good by appearing with it in an 
advertisement. ${ }^{1}$

In existing literature, theories related to celebrity endorsement generally focus on four major areas: effectiveness, function mechanisms, celebrity selection models, as well as problems involved. Literature on effectiveness of celebrity endorsement examines whether celebrity endorsers are more effective than non-celebrity endorsers and in what key aspects celebrity endorsement is most effective. Inconclusive and mixed findings in academic research flourish regarding this issue. On the one hand, celebrities create attention and bring prestige to brands, and may encourage higher recall (Erdogan, 1999; Tom et al., 1992). On the other hand, images of non-celebrity endorsers may be created and fine-tuned by the brand's company, and therefore, their images, personalities and actions can be ensured to fit with the brand's image.

Generally, there are three kinds of results concerning the effectiveness of celebrity and non-celebrity endorsement: some studies find that effects of celebrity endorsers are not significantly different from those of non-celebrity endorsers (Mehta, 1994) while other studies show that non-celebrity endorsers or "created" endorsers are more effective than celebrity endorsers (Tom et al., 1992) and still some other works find that celebrities are more effective than non-celebrities (Atkin and Block, 1983; Petty, Cacioppo and Schumann, 1983). It seems that no unified answer has been reached. However, from the financial perspective, using event studies, the findings indicate that using endorsers generates abnormal positive stock returns (Agrawal and Kamakura, 1995; Mathur, Mathur and Rangan, 1997). ${ }^{2}$

One key objective of advertising is to create brand awareness so that consumers recall the brand name outside the store or recognize it inside the store at the time of purchase (Rossiter and Percy, 1997). Celebrities are able to perform better than other endorsers (e.g. non-celebrity endorsers) in enhancing brand name recall (Friedman and Friedman, 1979; Petty et al., 1983). For example, a physically attractive celebrity paired with an attractiveness-related product could enhance name recall (Kahle and Homer, 1985). Literature has also studied attitude towards the brand and brand preference from different perspectives. Models of how advertising works suggest that, attitude towards the brand is also an important intermediate effect of advertising leading to behavioral intention and choice (Vakratsas and Ambler, 1999). Celebrity endorsement is expected to create brand preference so that consumers of the target products end up buying the brand endorsed by a celebrity.

What ultimately counts in celebrity endorsement in adverting is its level of persuasiveness. Benoit and Benoit (2008) define persuasion as "a process in which a source (persuader) uses a message to achieve a goal by creating, changing, or reinforcing the attitudes of others (the audience)." Seiter and Gass (2010) claim that persuasion is a special means of influence, but this special means of influence (i.e. persuasion) requires communication, through which persuasion can potentially influence the beliefs, attitudes, intentions, motivations and (ultimately) behaviors of consumers.

For over 2000 years, we have recognized that the source of a message can affect persuasion. In the fourth century BC, Aristotle observed that "we believe good men more fully and more readily than others; this is true generally whatever the question is, and absolutely where exact certainty is impossible and options divided". In modern times, it is also widely accepted that source credibility is an important factor in persuasion (Benoit, 1991; Hass, 1981). In advertising, the key role of the celebrity is to serve as the source of a message, which, in the current context, implies recommendation for products (or ideas or services). In this sense, the personalities, traits, and professional achievements of the celebrity matter a great deal to the persuasiveness of celebrity endorsement.

Models abound associated with studying persuasiveness of celebrity endorsed advertising. Some prominent models include the Source Credibility Model (Hovland, 1953; Ohanian, 1990), the Source Attractiveness Model (McGuire, 1985; Ohanian, 1990), the Match Up Hypothesis (Kamins, 1990; Till and Busler, 1998), and the Meaning Transfer Model (McCracken, 1989). These (and other) models highlight different aspects of how persuasion occurs.

The Source Credibility Model suggests that consumers' perception of a celebrity endorser's expertise and trustworthiness influences the effectiveness of the advertising message (Hovland and Weiss, 1951). Expertise is defined as "the extent to which a communicator is perceived to be a source of valid assertions" (Hovland et al., 1953). It refers to knowledge, experience or skills possessed by an endorser. Trustworthiness is defined as "the degree of confidence in the communicator's intent to communicate the assertions he considers most valid" (Hovland et. al 1953). It refers to honesty, integrity and believability of an endorser. There are limiting conditions to the source credibility model, as it has been suggested that if consumers have a positive predisposition toward an advertising message, a less credible source

\footnotetext{
${ }^{1}$ See also, for example, Patra and Datta (2010) for a slightly different definition.

2 Also, as expected, positive (negative) news about the celebrity endorser results in higher (lower) cash flow expectations (Russell, Mahar and Drewniak, 2005); the greater (lower) the perceived culpability of the celebrity involved in an undesirable event, the lower (greater) the stock return (Louie, Kulik and Jacobson, 2001).
} 
can be more persuasive than a more credible source (Erdogan, 1999; Harmon and Coney, 1982; Sternthal, Dholakia and Leavitt, 1978).

The Source Attractiveness Model is a component of the "Source Valence Model" of McGuire (Ohanian, 1990). ${ }^{3}$ It argues that the physical appeal of a celebrity influences the effectiveness of an advertising message (Baker and Churchill, 1977; Debevec and Kernan, 1984) and the consumer's intent to purchase (Friedman, Termini \& Washington, 1976). According to this model, the effectiveness of a message depends on sources" "similarity", "familiarity", "likeability", and "attractiveness" to the respondent. Source attractiveness has been studied from different perspectives by researchers (Kahle and Homer, 1985; McGuire 1985; Kamins, 1989, 1990; Till and Busler, 2000).

A significant portion of research in celebrity marketing examines how the fit between the celebrity's image and endorsed brand affects advertising attitudes, brand attitudes and purchase intent (Kamins, 1990; Misra and Beatty, 1990). Past works use various terms interchangeably to refer to the fit between celebrity and brand: congruence (Misra and Beatty, 1990; Fleck and Quester, 2007), consistency (Walker, Langmeyer and Langmeyer, 1992), fit and match (Kamins and Gupta, 1994) and match-up (Bower and Landreth, 2001). The Match Up Hypothesis suggests that the higher the perceived fit between the celebrity's image and the endorsed brand, the more persuasive the celebrity and the advertising will be (Erdogan, 1999; Kamins and Gupta, 1994).

The Meaning Transfer Model is an alternative model, which believes that celebrity endorsement is a special case of a more general process of meaning transfer (McCracken, 1989). The cultural meanings residing in a celebrity go beyond the person and are passed on to the products (McCracken, 1989; Brierley, 1995). There are three stages involved in the Meaning Transfer Model, namely, the formation of celebrity image, the transfer of meaning from the celebrity to the product and then from the product to the consumer. According to McCracken's (1989), symbolic properties of the celebrity first become associated with the brands the celebrity endorses. Then these symbolic meanings are transferred to consumers as they select brands with meanings congruent with their self-concept. Empirical tests of the Meaning Transfer Model are implemented by, for example, Langmeyer and Walker (1991a, b) and Escalas and Bettman (2009). These studies provide empirical evidence supporting the notion that brand endorsement by celebrities with an image that consumers aspire to obtain enhances consumers' self-brand connections.

Although most existing studies confirm the effects of celebrity endorsements, there are still various problems constantly occurring when using celebrities to endorse products in advertising. Among all, overshadowing the product and over-endorsement stand out. Often, it is seen that the target consumer focuses his/her attention on the celebrity and in the process may fail to notice the brand. This is the so-called overshadowing the product (Patra and Datta, 2010). In such a circumstance, the characteristics of the product are overshadowed by the celebrity's own appealing traits. As to the issue of over-endorsement, the effect of the endorser is cast in doubt. In China, over-endorsement is a special concern. With the explosive entry of luxurious global brands into the world's fastest growing market (China), finding suitable endorsers with national and international fame can be a challenge for advertisers (Chan, Hung, Tse and Tse, 2008). Researchers have found that the more products a celebrity endorses, the less credible he/she is treated by consumers (Kaikati, 1987; Mowen and Brown, 1981). This finding is not unreasonable. When a celebrity endorses a brand, the consumer associates the brand with the celebrity, allowing his or her expertise to transfer onto the brand. As the celebrity endorses more brands, however, the consumer may feel that the celebrity is losing his or her trustworthiness and commitment to the original brand. The consumer may also think that the celebrity is purely motivated by financial gains, which may in turn reduce his or her credibility. Indeed, some studies have confirmed a negative correlation between the number of brands endorsed by celebrities and consumers' preference toward the brands (Tripp, Jensen and Carlson, 1994). ${ }^{4}$

\section{Data, Variables and Descriptive Statistics}

The present paper contains an econometric analysis based on data obtained from extensive surveys. In this analysis, we empirically explore the various key influencing factors underpinning the persuasiveness of celebrity endorsed advertising. Our surveys are conducted in the context of the Chinese domestic markets.

We conduct our surveys by distributing questionnaire sheets to randomly chosen respondents. The respondents are requested to fill out the questionnaire sheets by answering carefully designed multiple-choice questions concerning their personal information (age group, gender, level of education, income category, etc.) and their expected reactions to

\footnotetext{
3 See, for example, McGuire (1985).

${ }^{4}$ For a wider range of discussions of advertising persuasiveness, see, for example, Anand and Sternthal (1992), Miniard, Barone, Rose and Kenneth (1994), Rosseli, Skelly and Mackie (1995), Lowrey (1998), Edwards and La Ferle (2009), Premeaux (2009), Zhang (2010), Zhen (2010), and Chan and Cheng (2012), to name but a few.
} 
hypothetical scenarios about advertising of certain categories of products where potential celebrity endorsement would occur. We divide the related target products into the following ten broad categories, which are (a) apparel (including garments, footwear and hats), (b) alcoholic drinks (including liquors, wines and beers), (c) durable household goods (e.g. durable household electric appliances such as air conditioners and washing machines), (d) private cars and motor cycles, (e) daily use household articles (such as shampoos, toothpastes and soaps), (f) OTC medicine and household health products (such as an air humidifier), (g) cosmetics, (h) cell phones, (i) snack foods (such as potato chips and instant noodles), and (j) various services (i.e. intangible products) related to areas such as telecommunication, banking, education, and tourism.

The central question to which we request an answer from the respondent is the hypothetical question of whether the respondent considers celebrity endorsement in advertising to be effective in persuading him or her to buy more of a certain product or brand (i.e. each category of, or a brand within each category of the products listed above), and if so, how much more (say, in a percentage measure) of the or brand he or she would be willing to buy, ceteris paribus, if the advertising of the product (brand) now gets endorsed by a celebrity. The respondent is asked essentially this same question with respect to each of the ten categories of products mentioned above. It should be noted that by doing so we are tracing out the shifts of the demand curve of the individual (potential) consumer for each of the markets of the ten categories of products. Needless to say, we expect that consumer characteristics may significantly affect the direction and magnitude of a shift in the individual consumer demand curve. In most cases, we expect a rightward shift of the individual consumer demand curve, where we know (from an introductory course in Economics) that a rightward shift of the demand curve implies a stronger preference for the product (brand), given other relevant factors held fixed. To gain a preliminary idea of our sample and data, we present a decomposition (distribution) of our sample in Table 1.

Our entire sample of people (those people who were surveyed and from whom we got valid responses) includes a total number of 1897 respondents. ${ }^{5}$ The sample is actually composed of two sub-samples obtained respectively in August 2013 and January 2014. Each row in Table 1 exhibits a certain characteristic of the respondent. The variables (characteristics) listed in Table 1 constitute the foundation for our subsequent regression analysis in the following section, though virtually all the variables displayed in Table 1 are qualitative in nature.

Table 1. Descriptive Statistics for the Entire Sample of People Surveyed

\begin{tabular}{|c|c|}
\hline \multicolumn{2}{|c|}{$\begin{array}{l}\text { Total sample size: } 1897 \text { (two sub-samples pooled together, dated Aug } 2013 \text { and Jan 2014) } \\
\text { First sub-sample: } 659(34.7 \%) \text {; second sub-sample: } 1238(65.3 \%)\end{array}$} \\
\hline Gender & Male: $784(41.3 \%) ;$ Female: $1113(58.7 \%)$ \\
\hline Age & $\begin{array}{l}18-27: 689(36.3 \%) ; 28-37: 756(39.9 \%) \\
38-47: 347(18.3 \%) ; 47+: 105(5.5 \%)\end{array}$ \\
\hline Education $^{(i)}$ & $\begin{array}{l}9-12: 423(22.3 \%) ; 13-16: 1239(65.3 \%) \\
17+: 235(12.4 \%)\end{array}$ \\
\hline Income $^{(\text {ii) }}$ & $\begin{array}{l}0-4: 542(28.6 \%) ; 5-9: 327(17.2 \%) ; 10-15: 464(24.5 \%) \\
16-20: 211(11.1 \%) ; 21+: 353(18.6 \%)\end{array}$ \\
\hline Area $^{(\text {iii })}$ & Rural: $679(35.8 \%) ;$ Urban: $1218(64.2 \%)$ \\
\hline Internet dependency ${ }^{\text {(iv) }}$ & $\begin{array}{l}\text { Heavy dependency: } 1036(54.6 \%) \\
\text { Non-heavy dependency: } 861(45.4 \%)\end{array}$ \\
\hline Proficiency in foreign language ${ }^{(v)}$ & $\begin{array}{l}\text { Zero and low: } 783(41.3 \%) \text {; Intermediate: } 987(52.0 \%) \text {; } \\
\text { High: } 127(6.7 \%)\end{array}$ \\
\hline Cell phone ${ }^{(v i)}$ & $\begin{array}{l}1000-: 242(12.8 \%) ; 1000-2000: 814(42.9 \%) \\
2000-3000: 593(31.3 \%) ; 3000+: 248(13.1 \%)\end{array}$ \\
\hline Married and having children ${ }^{\text {(vii) }}$ & Yes: 1137 (59.9\%); No: $760(40.1 \%)$ \\
\hline
\end{tabular}

Notes: (i) Education refers to formal schooling, which is measured in years. (ii) Income refers to annual before-tax income measured in 10 thousand RMB yuan. (iii) The area is divided according to the current location of residence of the respondent. (iv) Heavy dependency on the Internet refers to four hours' online time (or above) per day. (v) Zero to low proficiency in a foreign language roughly corresponds to a level of an average junior middle school student. Intermediate proficiency roughly corresponds to a level of an average college graduate while high proficiency roughly corresponds to a level of an average college graduate of a foreign language major. (vi) Price of cell phone refers to the

\footnotetext{
${ }^{5}$ Owing to space limit, we are not able to display the survey form (i.e. the questionnaire sheet) as an appendix to this paper. The survey form, however, is available from the authors upon request.
} 
re-purchase price of the cell phone the respondent is currently using, measured in RMB yuan. (vii) This indicates that the respondent is married and has at least one child.

Most information in Table 1 is self-evident, needing no further explanation. "Education" refers to formal schooling ever received by the respondent, which is measured in the total number of years. "Income" refers to the annual before-tax income earned by the respondent, which is measured in 10 thousand RMB yuan. The "Area" refers the current location (i.e. at the time the survey was conducted) of residence of the respondent, which is divided into the rural area and the urban area. "Heavy dependency on the Internet (or not)", which we see as an important and meaningful proxy variable for a host of underlying traits of the respondent, refers to more than four hours' online time spent (i.e. total hours spent being on the internet) per day. Proficiency in a foreign language (usually English) is what we consider as another important proxy variable for a variety of unobserved characteristics of the respondent. Zero to low proficiency in a foreign language roughly corresponds to a level of an average junior middle school student while intermediate proficiency roughly corresponds to a level of an average college graduate, and high proficiency roughly corresponds to a level of an average college graduate of a foreign language major. The "Price of cell phone" item, which is probably a reasonable and observable proxy variable, say, for the respondent's sensitivity toward and preference for vogue and fashion, refers to the re-purchase price of the cell phone the respondent is currently using, which is measured in RMB yuan. The last row of Table 1 indicates that the respondent is married and has at least one child.

All those qualitative characteristics of the surveyed respondents listed in Table 1 (as well as possible interactions among these characteristics) will serve as potential explanatory variables explaining a possible change in consumer behavior induced by consumer preferences triggered by celebrity endorsement in advertising.

\section{Econometric Analysis and Regression Results}

In this study, we are interested in exploring the potential effects of a host of key factors on the level of persuasiveness provided by celebrity endorsement in advertising. Specifically, we are interested in seeing the effects of those respondent (consumer) characteristics on the level of persuasiveness of celebrity endorsement in advertising. Ideally, persuasiveness of celebrity endorsement per se, if directly observable, should show up on the left-hand side of the regression model as the variable to be explained. However, persuasiveness of celebrity endorsement is not directly measurable. Therefore, we use the (expected) change (in percentage terms) of quantity demanded (consumed) for the product as an indicator variable for the level of persuasiveness of celebrity endorsement in advertising.

Our baseline regression specification can be designed as follows

$$
\begin{gathered}
\% \Delta Q_{i}^{k}=\beta_{0}+\sum_{j} \sum_{h} \beta_{j h} d_{j h i}+\varepsilon_{i} \\
=\beta_{0}+\beta_{11} d_{11 i}+\sum_{h=1}^{3} \beta_{2 h} d_{2 h i}+\sum_{h=1}^{2} \beta_{3 h} d_{3 h i}+\sum_{h=1}^{4} \beta_{4 h} d_{4 h i}+\beta_{51} d_{51 i} \\
+\beta_{61} d_{61 i}+\sum_{h=1}^{2} \beta_{7 h} d_{7 h i}+\sum_{h=1}^{3} \beta_{8 h} d_{8 h i}+\beta_{91} d_{91 i}+\varepsilon_{i}
\end{gathered}
$$

where $k$ indexes the different categories of products involved in the surveys which were discussed earlier, $i$ indexes the cross sectional units which are (in the current case) the individual respondents surveyed, $j$ indexes the various consumer characteristics listed in Table 1, and $h$ indexes the different groups of respondents (consumers) divided according to each of the consumer characteristics. $\beta_{0}$ denotes the common intercept of the regression. The $d$ 's are binary (dummy) variables and the accompanying coefficients, the $\beta$ 's, are each interpreted as an additional intercept compared with the corresponding base group. Finally, $\varepsilon_{i}$ is error term of the regression whose mean can be assumed zero. In our regression analysis to come, we use equation (1) as our baseline regression specification. Table 2 provides a detailed description of the variables and accompanying coefficients that appear in equation (1).

A variant version of the regression specification in (1) can be designed so that the dependent variable on the left-hand side of the equation is a binary variable. The equation is then written as

$$
\begin{gathered}
\text { eff }{ }_{i}^{k}=\beta_{0}+\sum_{j} \sum_{h} \beta_{j h} d_{j h i}+\varepsilon_{i} \\
=\beta_{0}+\beta_{11} d_{11 i}+\sum_{h=1}^{3} \beta_{2 h} d_{2 h i}+\sum_{h=1}^{2} \beta_{3 h} d_{3 h i}+\sum_{h=1}^{4} \beta_{4 h} d_{4 h i}+\beta_{51} d_{51 i} \\
+\beta_{61} d_{61 i}+\sum_{h=1}^{2} \beta_{7 h} d_{7 h i}+\sum_{h=1}^{3} \beta_{8 h} d_{8 h i}+\beta_{91} d_{91 i}+\varepsilon_{i}
\end{gathered}
$$

where the explained variable $e f f_{i}^{k}$ is a binary variable taking only the two values zero and one, that is, eff ${ }_{i}^{k}=1$ indicates consumer (respondent) $i$, when being surveyed, thinks that for a certain product (brand) $k$, celebrity endorsement in advertising generates effective persuasion, and eff $_{i}^{k}=0$ otherwise. The model in (2) is a linear probability model (LPM), where the dependent variable is associated with a probability interpretation, namely 


$$
\operatorname{Pr}\left(e f f_{i}^{k}=1 \mid \mathbf{d}_{i}\right)=\beta_{0}+\sum_{j} \sum_{h} \beta_{j h} d_{j h i}
$$

which says that the probability of "success" (i.e. effective persuasion generated by celebrity endorsement in advertising), say, $p(\mathbf{d})=\operatorname{Pr}\left(e f f^{k}=1 \mid \mathbf{d}\right)$, is a linear function of $\mathbf{d}$, where $\mathbf{d}$ is shorthand for all the explanatory variables (which all happen to be binary variables in the current case).

Table 2. The Variables and Coefficients in the Regression Equations (1) and (2)

\begin{tabular}{|c|c|}
\hline \multicolumn{2}{|c|}{$\begin{array}{l}\text { Explained variable: (a) } \% \Delta Q^{k} \text {, percentage change in the quantity consumed of product } k \text {; } \\
\text { (b) eff , binary variable; eff }=1 \text { indicates effective celebrity endorsement }\end{array}$} \\
\hline \multicolumn{2}{|c|}{ The explanatory variables are defined as follows } \\
\hline Gender & $\begin{array}{l}\text { Base group: Male; } \\
d_{11}=1: \text { Female; }\left(\beta_{11}\right)\end{array}$ \\
\hline Age & $\begin{array}{l}\text { Base group: } 18-27 \\
d_{21}=1: 28-37 ;\left(\beta_{21}\right) \\
d_{22}=1: 38-47 ;\left(\beta_{22}\right) \\
d_{23}=1: 47+;\left(\beta_{23}\right)\end{array}$ \\
\hline Education & $\begin{array}{l}\text { Base group: } 9-12 \\
d_{31}=1: 13-16 ;\left(\beta_{31}\right) \\
d_{32}=1: 17+;\left(\beta_{32}\right)\end{array}$ \\
\hline Income & $\begin{array}{l}\text { Base group: } 0-4 ; \\
d_{41}=1: 5-9 ;\left(\beta_{41}\right) \\
d_{42}=1: 10-15 ;\left(\beta_{42}\right) \\
d_{43}=1: 16-20 ;\left(\beta_{43}\right) \\
d_{44}=1: 21+;\left(\beta_{44}\right)\end{array}$ \\
\hline Area & $\begin{array}{l}\text { Base group: Rural; } \\
d_{51}=1: \text { Urban; }\left(\beta_{51}\right)\end{array}$ \\
\hline Internet dependency & $\begin{array}{l}\text { Base group: Heavy dependency; } \\
d_{61}=1: \text { Non-heavy dependency; }\left(\beta_{61}\right)\end{array}$ \\
\hline Proficiency in foreign language & $\begin{array}{l}\text { Base group: Zero and low; } \\
d_{71}=1: \text { Intermediate; }\left(\beta_{71}\right) \\
d_{72}=1: \operatorname{High} ;\left(\beta_{72}\right)\end{array}$ \\
\hline Cell phone & $\begin{array}{l}\text { Base group: 1000-; } \\
d_{81}=1: 1000-2000 ;\left(\beta_{81}\right) \\
d_{82}=1 ; 2000-3000 ;\left(\beta_{82}\right) \\
d_{83}=1: 3000+;\left(\beta_{83}\right)\end{array}$ \\
\hline Married and having children & $\begin{array}{l}\text { Base group: "Yes"; } \\
d_{91}=1 \text { : "No"; }\left(\beta_{91}\right)\end{array}$ \\
\hline
\end{tabular}

Notes: Variables are defined to capture the individual consumer characteristics shown in Table 1. Accompanying coefficients are defined and shown in parentheses. The defined variables and coefficients appear in equations (1) and (2), both of which constitute the econometric framework within which relevant regressions are performed.

We run a cross section Ordinary Least Squares (OLS) regression respectively for each of the product type $k$ according to equations (1) and (2), based on data obtained from the surveys. A prominent result we find is that the two version of the regression model do not yield estimation results that are substantively different. To save space, we report only regression results generated by equation (2), as the specification in (2) provides a more interesting interpretation of the estimated coefficients on the explanatory variables. Regression results based on equation (2) are summarized in Table 3 for a few selected product categories $k{ }^{6}{ }^{6}$ With respect to these selected product categories, our model generally works better and produces more estimates that are statistically significant and economically meaningful, compared with the product categories we leave out.

${ }^{6}$ We do not display results for all the product categories for the sake of saving space. 
Table 3. Estimation Results Based on Equation (2)

\begin{tabular}{cccccc}
\hline \multicolumn{5}{c}{ Dependent variable: eff } \\
\hline & \multicolumn{5}{c}{ Product category } \\
\cline { 2 - 6 } Coefficient & (a) & (c) & (e) & $(\mathrm{g})$ & (i) \\
\hline$\beta_{0}$ & 0.163 & 0.089 & 0.137 & 0.062 & 0.148 \\
\hline$\beta_{11}$ & 0.212 & 0.041 & 0.158 & 0.203 & 0.095 \\
\hline$\beta_{21}$ & n.s. & n.s. & n.s. & 0.020 & n.s. \\
$\beta_{22}$ & n.s. & n.s. & n.s. & n.s. & n.s. \\
$\beta_{23}$ & n.s. & n.s. & n.s & -0.014 & -0.023 \\
\hline$\beta_{31}$ & -0.015 & n.s. & 0.019 & n.s. & 0.031 \\
$\beta_{32}$ & -0.018 & n.s. & 0.010 & n.s. & 0.024 \\
\hline$\beta_{41}$ & 0.041 & 0.017 & 0.025 & 0.032 & 0.009 \\
$\beta_{42}$ & 0.033 & 0.018 & -0.013 & 0.042 & n.s. \\
$\beta_{43}$ & 0.038 & 0.031 & -0.017 & 0.014 & n.s. \\
$\beta_{44}$ & -0.010 & 0.021 & 0.029 & 0.035 & n.s. \\
\hline$\beta_{51}$ & n.s. & 0.015 & n.s. & 0.021 & -0.018 \\
\hline$\beta_{61}$ & -0.012 & -0.009 & 0.020 & n.s. & n.s. \\
\hline$\beta_{71}$ & 0.016 & n.s. & n.s. & -0.010 & n.s. \\
$\beta_{72}$ & n.s. & n.s. & n.s. & 0.014 & n.s. \\
\hline$\beta_{81}$ & 0.009 & n.s. & 0.012 & 0.015 & 0.010 \\
$\beta_{82}$ & n.s. & n.s. & 0.019 & 0.039 & 0.022 \\
$\beta_{83}$ & 0.024 & 0.026 & 0.033 & 0.029 & 0.016 \\
\hline$\beta_{91}$ & 0.022 & 0.013 & 0.036 & n.s. & n.s. \\
\hline
\end{tabular}

Notes: Estimates of the coefficients are shown in this table. Insignificant estimates (at the 5\% level) are not explicitly reported and are indicated by "n.s." (for "not significant"). To save space, standard errors, p-values or confidence intervals are not reported in this table. The product categories include (a) apparel, (b) alcoholic drinks, (c) durable household goods, (d) private cars and motor cycles, (e) daily use household articles, (f) OTC medicine and household health products, (g) cosmetics, (h) cell phones, (i) snack foods, and (j) various services (see the text for more detail). Estimation results associated with five out of the ten product categories above, namely, (a), (c), (e), (g) and (i) are reported in this table.

We can see from Table 3 that consumer demands for the different types of products exhibit differential features in terms of consumers' responses to advertising with celebrity endorsement. The estimated values of the coefficients vary quite discernibly across different types of products. It should be noted that the values bear a probability interpretation. For example, the first value in the column for product (a), i.e. 0.163, reveals that for the base group (i.e. male, aged 18-27, 9-12 years of schooling, annual income of 0-40 thousand RMB yuan, living in the rural area, heavily dependent on the internet access, zero or low level of foreign language proficiency, using a cell phone priced below one thousand RMB yuan, and married and having children) of the surveyed consumers, the probability of advertising with celebrity endorsement in product (a) being effective is 0.163 . Similarly, with respect to the cohort of consumers who are female, aged 18-27, with 9-12 years of schooling and an annual income within the range of 0-40 thousand RMB yuan, living in the rural area, heavily dependent on the internet access, with zero or a low level of foreign language proficiency, using a cell phone priced below one thousand RMB yuan, and married and having children, the probability of advertising with celebrity endorsement in product (a) being effective is $0.163+0.212=0.375$.

One important and interesting finding we obtain from Table 3 is that gender matters substantially in determining the level of effectiveness that persuasion of celebrity endorsed advertising could possibly reach. Our regression analysis shows that in general celebrity endorsed advertising is more successful in terms of persuasiveness with respect to female target consumers. Another important factor affecting the level of persuasiveness of celebrity endorsed advertising is income. Across different income cohorts of consumers, even the same product may have different magnitudes and signs (i.e. positive or negative signs) of income elasticities, which are dependent on the underlying consumer preferences. Our regression results show that the level of the consumer's income interacts with the level of effectiveness of celebrity endorsed advertising with respect to each type of product shown in Table 3. Still another important factor affecting the level of persuasiveness of celebrity endorsed advertising is the price range of the cell phone the consumer uses, which can be perceived as a proxy or indicator variable for a certain part of the socio-cultural background of the consumer (noting that the partial effect of the consumer income has already been netted out). 
However, besides all the salient findings provided by our regressions in Table 3, one shortcoming exists in our regression specifications in (1) and (2), which is that they overlook potential interactions between the explanatory variables. In other words, the models assume separate and isolated partial effects of the explanatory variables. For example, without including the interaction terms in the regression equation, the "urban premium" (as reflected by the coefficient $\beta_{51}$ ) is assumed to be the same for men and women (and so on), which is an undesirable limitation of the specifications in (1) and (2). In contrast, allowing for, say, differential "urban premiums" for male and female makes the problem more interesting. Therefore, interactions between explanatory variables ought to be taken into consideration, and we need to improve our regression framework along this line, though the inclusion of interaction terms may heavily complicate the interpretation of our regression results.

Dealing with the interaction terms can be a formidable task, as we have so many explanatory variables included in the specifications. Nevertheless, our regression exercise based on equations (1) and (2) does provide us with a rough idea for seeing which are those relatively more important explanatory variables that exert relatively larger partial impacts on the dependent variable than the others. We can thus cut the number of explanatory variables, keeping in the regression equation only those that are relatively more important before we think about including the interaction terms in the equation. As discussed above, we find that gender and income are the two most important (and perhaps more fundamental) factors that influence the outcome of the dependent variable. Therefore, in order to accommodate the interactions between explanatory variables without at the same time making the issue overwhelmingly complicated, we reduce the number of explanatory variables to only two (i.e. gender and income, not counting their interaction terms). By doing so, we can afford a regression model with the full set of interaction terms included.

Therefore, we run a new round of regressions base on the following new specification

$$
\begin{gathered}
\text { eff }_{i}^{k}=\delta_{0}+\varphi_{0} d_{11 i}+\sum_{h=1}^{4}\left(\delta_{4 h}+\varphi_{h} d_{11 i}\right) d_{4 h i}+u_{i} \\
=\delta_{0}+\varphi_{0} d_{11 i}+\delta_{41} d_{41 i}+\delta_{42} d_{42 i}+\delta_{43} d_{43 i}+\delta_{44} d_{44 i}+\varphi_{1} d_{11 i} d_{41 i} \\
+\varphi_{2} d_{11 i} d_{42 i}+\varphi_{3} d_{11 i} d_{43 i}+\varphi_{4} d_{11 i} d_{44 i}+u_{i}
\end{gathered}
$$

where the $d$ 's follow the same definitions as in Table 2, and the $\delta$ 's and $\varphi$ 's are the new coefficients to be estimated. Two findings stand out from our regression results. One is that all of the estimated coefficients on the interaction terms, i.e. the $\varphi$ 's, are insignificant (at the usual $5 \%$ level). The second finding is that when the interaction terms are ignored (as they are shown to have insignificant partial effects), the estimated coefficients on the other terms (i.e. the $\delta$ 's) do not lead to any significantly different results from those provided by our previous regressions in Table 3 . In sum, this new round of regression exercise turns out to confirm and reinforce the essential results generated by our earlier regressions.

\section{Concluding Remarks}

In this study, we aim to empirically examine the potential roles of a host of key factors on the part of the consumer in affecting the level of persuasiveness provided by celebrity endorsement in advertising. Specifically, we focus on the effects of various consumer characteristics on the expected persuasiveness level of celebrity endorsed advertising. Based on first-hand survey data, we set up our econometric models and run related regressions. Our estimation results show that gender matters crucially in determining the level of effectiveness that persuasion of celebrity endorsed advertising could possibly reach. That is, celebrity endorsed advertising is in general more successful in its persuasiveness with respect to female target consumers. Another important factor we find affecting the effectiveness of celebrity endorsed advertising is the level of the consumer's income. Our results show that the level of the consumer's income interacts with the level of effectiveness of celebrity endorsed advertising with respect to the various types of products we select. Our empirical results also suggest that the socio-cultural background of the consumer plays a critical role in affecting the persuasiveness level of celebrity endorsed advertising. Hopefully, the methodology and findings of this study can motivate further research in this direction and help advertisers design better forms of celebrity endorsed advertising for their target customers.

\section{Acknowledgements}

The authors thank the two anonymous reviewers and the editors of the Journal for their comments and suggestions.

\section{References}

Agrawal, J., \& Kamakura, W.A. (1995). The Economic Worth of Celebrity Endorsers: an Event Study Analysis. Journal of Marketing, 59, 56-62.

Atkin, C., \& Block, M. (1983). Effectiveness of Celebrity Endorsers. Journal of Advertising Research, 23, 57-61. 
Baker, M. J., \& Churchill, G. A., Jr. (1977). The Impact of Physically Attractive Models on Advertising Evaluations. Journal of Marketing Research, 14, 538-555.

Benoit, W. L., \& Benoit, P. J. (2008). Persuasive Messages: the Process of Influence. Blackwell Publishing.

Bower, A. B., \& Landreth, S. (2001). Is Beauty Best? Highly versus Normally Attractive Models in Advertising. Journal of Advertising, 30, 1-12. http:/dx.doi.org/doi:10.1080/00913367.2001.10673627

Brierley, S. (1995). The Advertising Handbook London: Routledge.

Chan, K., \& Cheng, Y. (2012). Portrayal of Females in Magazine Advertisements in Hong Kong. Journal of Asian Pacific Communication, 22(1), 78-96.

Chan, K. W., Hung, K., Tse, C. H., \& Tse, D. K. (2008). Understanding Celebrity Endorser Effects in China: a Consumer-Celebrity Relational Perspective. Proceedings of GMC Shanghai Conference.

Debevec, K., \& Kernan, J. (1984). More Evidence on the Effects of a Presenter's Physical Attractiveness: Some Cognitive, Affective, and Behavioral Consequence. Advances in Consumer Research, 11, 127-132.

Edwards, S. M., \& La Ferle, C. (2009). Does Gender Impact the Perception of Negative Information Related to Celebrity Endorsers? Journal of Promotion Management, 15(1/2), 22-35. http://dx.doi.org/doi:10.1080/10496490902837940

Erdogan, B. Z. (1999). Celebrity Endorsement: A Literature Review. Journal of Marketing Management, 15, 291-314. http:/dx.doi.org/doi:10.1362/026725799784870379

Escalas, J. E., \& Bettman, J. R. (2009). Connecting with Celebrities: Celebrity Endorsement, Brand Meaning, and Self-Brand Connections. (Working Paper)

Fleck, N. D., \& Quester, P. (2007). Birds of a Feather Flock Together...Definition, Role and Measure of Congruence: an Application to Sponsorship. Psychology \& Marketing, 24, 975-1000.

Friedman, H. H., \& Friedman, L. (1979). Endorser Effectiveness by Product Type. Journal of Advertising Research, 19(5), 63-71.

Friedman, H. H., Termini, S., \& Washington, R. (1976). The Effectiveness of Advertisements Utilizing Four Types of Endorsers. Journal of Advertising, 5, 22-24. http://dx.doi.org/doi:10.1080/00913367.1976.10672647

Harmon, R. R., \& Coney, K. A. (1982). The Persuasive Effects of Source Credibility in Buy and Lease Situations. Journal of Marketing Research (JMR), 19, 255-260.

Hass, R. G. (1981). Effects of Source Characteristics on Cognitive Responses and Persuasion. In R.E. Petty, T.M.Ostrom, and T.C.Brock (eds), Cognitive Responses in Persuasion, 44-72. Hillsdale: Erlbaum.

Hovland, C., Janis, L. I., \& Kelley, H. (1953). Communication and Persuasion. New Haven, CT: Yale University Press.

Hovland, C. I. \& Walter, W. (1951). The Influence of Source Credibility on Communication Effectiveness. Public Opinion Quarterly, 15, Winter, 635-650.

Kahle, L. R., \& Homer, P. (1985). Physical Attractiveness of the Celebrity Endorser: a Social Adaptation Perspective. Journal of Consumer Research, 11(4), 954-961.

Kaikati, J. G. (1987). Celebrity Advertising: a Review and Synthesis. International Journal of Advertising, 6(2), 93-105.

Kamins, M. A. (1989). Celebrity and Noncelebrity Advertising in a Two-sided Context. Journal of Advertising Research, $29,34-42$.

Kamins, M. A. (1990). An Investigation into the Match-Up-Hypothesis in Celebrity Advertising: When Beauty Be only Skin Deep. Journal of Advertising, 19(1), 4-13. http://dx.doi.org/doi:10.1080/00913367.1990.10673175

Kamins, M. A., \& Gupta, K. (1994). Congruence between Spokesperson and Product Type: A Matchup Hypothesis Perspective. Journal of Psychology \& Marketing, 11, 569-586.

Langmeyer, L., \& Walker, M. (1991a). A First Step to Identify the Meaning in Celebrity Endorsers. In: Advances in Consumer Research (Eds). Rebecca R Holman and Michael R Solomon, Vol. 18, Provo, Utah: Association for Consumer Research, 364-371.

Langmeyer, L., \& Walker, M. (1991b). Assessing the Affects of Celebrity Endorsers: Preliminary Findings. In: American Academy of Advertising Proceedings (Eds). Rebecca R Holman, 32-42.

Louie, T., Kulik, R., \& Jacobson, R. (2001). When Bad Things Happen to the Endorsers of Good Products. Marketing Letters, 12, 13-23. 
Mathur, L. K., Mathur, I., \& Rangan N. (1997). The Wealth Effects Associated with a Celebrity Endorser: the Michael Jordan Phenomenon. Journal of Advertising Research, 37, 67-73.

McCracken, G. (1989). Who is the Celebrity Endorser? Cultural Foundations of the Endorsement Process. Journal of Consumer Research, 16(December), 130-169.

McGuire, W. J. (1985). Attitudes and Attitude Change. In: Handbook of Social Psychology (Eds). Gardner Lindzey and Elliot Aronson, Vol. 2 NY Random House, 233-346.

Mehta, A. (1994). How Advertising Response Modeling (ARM) can Increase Ad Effectiveness. Journal of Advertising Research, 34, 62-74.

Misra, S., \& Beatty, S. E. (1990). Celebrity Spokesperson and Brand Congruence: an Assessment of Recall and Affect. Journal of Business Research, 21, 159-171.

Mowen, J. C., \& Brown, S. W. (1981). On Explaining and Predicting the Effectiveness of Celebrity Endorsers. Advances in Consumer Research (Eds). Kent B. Monroe, Ann Arbor, MI: Association for Consumer Research, 437-441.

Ohanian, R. (1990). Construction and Validation of a Scale to Measure Celebrity Endorser's Perceived Expertise, Trustworthiness, and Attractiveness. Journal of Advertising, 19, 39-52. http://dx.doi.org/doi:10.1080/00913367.1990.10673191

Patra, S., \& Datta, S. K. (2010). Celebrity Endorsement in India-Emerging Trends and Challenges. Journal of Marketing \& Communication, January-April, 16-23.

Petty, R. E., Cacioppo, J., \& Schumann, D. (1983). Central and Peripheral Routes to Advertising Effectiveness: the Moderating Role Involvement. Journal of Consumer Research, 10, 135-146.

Premeaux, S. R. (2009). The Attitudes of Middle Class versus Upper Class Male and Female Consumers Regarding the Effectiveness of Celebrity Endorsers. Journal of Promotion Management, 15(1/2), 2-21. http://dx.doi.org/doi:10.1080/10496490902854820

Rossiter, J. R., \& Percy, L. (1987). Advertising and Promotion Management London: McGraw-Hill, Inc.

Russel, M., Mahar, J., \& Drewniak, B. (2005). Examination of Stock Market Response to Publicity Surrounding Athletic Endorsers. Journal of Marketing Management, 15, 67-79.

Sternthal, B., Dholakia, R., \& Leavitt, C. (1978). The Persuasive Effect of Source Credibility: Tests of Cognitive Response. Journal of Consumer Research, 4, 252-260.

Till, B. D., \& Busier, M. (1998). Matching Products with Endorsers: Attractiveness Versus Expertise. Journal of Consumer Marketing, 15(6), 576-586.

Till, B. D., \& Busler, M. (2000). The Match-up Hypothesis: Physical Attractiveness, Expertise, and the Role of Fit on Brand Attitude, Purchase Intent and Brand Beliefs. Journal of Advertising, 29, 1-13. http://dx.doi.org/doi:10.1080/00913367.2000.10673613

Tom, G., Clark, R., Elmer, L., Grech, E., Masetti, J., \& Sandhar, H. (1992). The Use of Created Versus Celebrity Spokesperson in Advertisement. Journal of Consumer Marketing, 9, 45-51.

Tripp, C., Jensen, T. D., \& Carlson, L. (1994). The Effects of Multiple Product Endorsements by Celebrities on Consumers' Attitudes and Intensions. Journal of Consumer Research, 20, March, 535-547.

Vakratsas, D., \& Tim A. (1999). How Advertising Works; What Do We Really Know? Journal of Marketing, 63 (January), 26-43.

Walker, M., Langmeyer, L., \& Langmeyer, D. (1992). Celebrity Endorsers: Do You Get What You Pay For? Journal of Services Marketing, 6, 35-42.

Zhen, S. (2010). Chinese Celebrity-Endorsed TV Commercials: A Content Analysis. China Media Research, 6(2), 34-46.

\section{(cc) $\mathrm{EY}$}

This work is licensed under a Creative Commons Attribution 3.0 License. 